\title{
THINK TALK WRITE SEBAGAI UPAYA MENINGKATKAN KOMUNIKASI MATEMATIS SISWA
}

\author{
Pipit Retnowati ${ }^{1}$, Arta Ekayanti ${ }^{2}$ \\ Program Studi Pendidikan Matematika, Universitas Muhammadiyah Ponorogo \\ Email: pipitretnowati393@gmail.com
}

\begin{abstract}
Abstrak:
Komunikasi matematis merupakan kemampuan siswa dalam menjelaskan suatu ide dari hasil pemikiran dengan gambar, diagram, atau simbol matematika secara lisan maupun tulisan, sehingga komunikasi matematis sangat penting untuk dimiliki siswa. Diantara model pembelajaran yang dapat diterapkan dalam proses pembelajaran adalah model pembelajaran Think Talk Write (TTW). Dengan menerapkan Think Talk Write (TTW) siswa mampu melatih kemampuan komunikasi matematisnya baik secara lisan maupun tulisan. Hal ini berdasarkan langkah-langkah Think Talk Write (TTW) yaitu berpikir (think), berbicara (talk) dan menulis (write) yang sangat dimungkinkan dapat meningkatkan kemampuan komunikasi matematis siswa. Dikarenakan dalam model pembelajaran Think Talk Write (TTW) siswa dilatih untuk berpikir secara mandiri dari berbagai sumber belajar. Langkah-langkah Think Talk Write (TTW) juga melatih siswa untuk berbicara menyampaikan ide dari gagasan yang telah ditemukan dan menuliskan hasil pembahasan dengan bahasanya sendiri. Kedua langkah tersebut membiasakan siswa untuk melatih kemampuan komunikasi matematis siswa baik secara lisan maupun tulis
\end{abstract}

Kata Kunci: Komunikasi Matematis, Think Talk Write (TTW)

\begin{abstract}
:
Mathematical communication is the ability of students to explain an idea from the results of thinking with pictures, diagrams, or mathematical symbols verbally or in writing, so mathematical communication is very important for students to have. Among the learning models that can be applied in the learning process are Think Talk Write (TTW) learning models. By implementing Think Talk Write (TTW) students are expected to be able to practice their mathematical communication skills both orally and in writing. Based on the steps of Think Talk Write (TTW) namely thinking, speaking and writing it is very possible to improve students' mathematical communication skills. Because in the Think Talk Write (TTW) learning model students are trained to think independently of various learning sources. Steps of Think Talk Write (TTW) also trains students to speak to convey ideas from the ideas that have been found and to obtain the results of the discussion in their own language. Both of these steps accustom students to practice mathematical communication skills of students both verbally and in writing
\end{abstract}

Keywords: Mathematical Communication, Think Talk Write (TTW)

\section{Pendahuluan}

Komunikasi adalah salah satu cara seseorang menyampaikan ide dan gagasan yang ada dalam pikirannya kepada orang lain. Kemampuan komunikasi yang baik merupakan salah satu hal yang dapat menentukan kesuksesan seseorang. Begitu pula dalam proses pembelajaran, apabila siswa memiliki kemampuan berkomunikasi yang rendah maka proses pembelajaran tidak akan berlangsung secara optimal. Hal ini sejalan dengan pendapat (Inah, 2015: 150) yang menyatakan bahwa proses pembelajaran akan efektif jika terjadi komunikasi secara intensif antara guru dan siswa yang memiliki komunikasi yang baik. (Khoiruddin 2012:118) menyatakan bahwa kemampuan komunikasi yang terjalin dengan baik antara siswa dengan guru dapat membantu dalam mencapai tujuan pembelajaran yaitu terjadinya perubahan tingkah laku dalam diri siswa. Hal ini menunjukkan bahwa kemampuan berkomunikasi merupakan komponen penting dalam proses pembelajaran, termasuk pembelajaran matematika. 
Matematika adalah dasar dari ilmu pengetahuan yang dapat melatih siswa berpikir secara sistematis. Dengan belajar matematika siswa diharapkan mampu memiliki kemampuan berpikir sistematis , tersebut, namun ternyata kemampuan belajar matematika siswa di Indonesia masih rendah. Menurut survei yang dilakukan oleh The Trends in International Mathematics and Science Study (TIMSS) pada siswa kelas VIII tahun 2011, Indonesia menempati urutan ke-32 dari 49 negara di dunia. Program for International Student Assesment (PISA) juga menujukkan hasil bahwa Indonesia menempati peringkat 64 dari 65 negara di dunia. Hal ini juga tidak jauh berbeda dari hasil TIMSS 2015 yang dipublikasikan pada Desember 2016 bahwa prestasi siswa di bidang matematika mendapat peringkat 46 dari 51 negara dengan skor 397. Hasil TIMSS yang rendah tersebut tentunya disebabkan oleh banyak faktor. Menurut (Wardhani \& Rumiati, 2011: 1) salah satu faktor penyebabnya adalah kurangnya siswa dalam mengerjakan soal yang memerlukan argumentasi dalam penyelesaiannya. Kemampuan menyusun argumentasi merupakan salah satu indikator kemampuan komunikasi matematis, dimana indikator tersebut merupakan acuan baik atau tidaknya kemampuan komunikasi matematis siswa.

Komunikasi matematis merupakan kemampuan siswa dalam mengungkapkan ide-ide matematika secara lisan, tertulis, gambar, diagram, menggunakan benda nyata, atau menggunakan simbol matematika (NCTM, 2000) Melalui komunikasi matematis siswa diharapkan dapat menyampaikan ide dan gagasanya baik dalam lisan maupun tulisan. Sebab beberapa siswa hanya mampu menyampaikan idenya lewat tulisan tapi tidak mampu menyampaikannya secara lisan atau sebaliknya siswa dapat menyelesaikan soal-soal dengan baik tetapi tidak dapat menjelaskan kepada temannya. Namun hal yang perlu diperhatikan dalam mengkomunikasikan ide tersebut siswa harus berusaha agar tidak menimbulkan kesalahapahaman ketika mengkomunikasikan suatu konsep matematis.
Kemampuan komunikasi matematis merupakan salah satu hal yang diperlukan dalam proses pembelajaran matematika. (NCTM: 2000: 4) menyatakan bahwa komunikasi matematis perlu menjadi fokus perhatian dalam proses pembelajaran matematika, karena melalui komunikasi siswa dapat mengorganisasi dan mengkonsilidasi berpikir matematisnya. Ketika kemampuan komunikasi matematis siswa dalam pembelajaran rendah karena tidak dapat menyampaikan ide dan gagasannya secara sistematis maka dapat mempengaruhi jalannya proses pembelajaran. Kemampuan komunikasi matematis tidak hanya diperlukan dalam proses pembelajaran tetapi juga harus dimiliki oleh siswa karena dapat menjadi suatu tantangan bagi siswa untuk mampu berpikir dan bernalar tentang matematika.

$$
\text { Menurut (Andriani, 2019: 23) }
$$

untuk dapat meningkatkan dan menumbuhkan kemampuan komunikasi siswa baik lisan dan tulis diperlukan model pembelajaran yang tepat agar siswa dapat belajar secara aktif dan optimal dalam meningkatkan kemampuan tersebut. Model pembelajaran kooperatif yang dapat digunakan untuk melatih kemampuan komunikasi matematis adalah Think Talk Write (TTW). Model pembelajaran Think Talk Write (TTW) dapat meningkatkan kemampuan komunikasi matematis dimana siswa dapat belajar secara individu atau kelompok dengan segala kegiatan yang berlangsung dalam proses pembelajaran dengan berbagai sumber belajar (Sumirat, 2014: 2).(Lusi Ari Sumirat, 2014) Hal ini juga sejalan dengan pendapat (Winayawati, 2012: 70) yang menyatakan pembelajaran matematika menggunakan model pembelajaran Think Talk Write (TTW) dapat meningkatkan kemampuan komunikasi matematis siswa.

Dalam Think Talk Write (TTW) siswa dilatih berpikir untuk menemukan suatu suatu permasalahan dari berbagai sumber belajar, berbicara untuk menyampaikan gagasan dari permasalahan yang ditemukan dan juga menulis hasil pembahasan dengan bahasanya sendiri. Sehingga kiranya langkah-langkah Think Talk Write (TTW) dapat meningkatkan 
komunikasi matematis siswa, maka dari itu keterkaitan antara langkah-langkah Think Talk Write (TTW) dalam meningkatkan komunikasi matematis siswa menarik untuk diteliti lebih lanjut.

\section{Metode}

Metode yang digunakan untuk artikel ini adalah studi literatur yang dikaji dari berbagai sumber. (Nazir, 2003: 27) menyatakan bahwa studi literatur adalah studi penelahaan terhadap buku-buku literatur, catatan, dan laporan-laporan yang ada hubungan dengan masalah yang dipecahkan. Pengumpulan data menggunakan metode observasi yang memuat data yang diambil dari kata, klausa, dan kalimat dari sumber pustaka yang berkaitan mengenai Think Thank Write (TTW) sebagai upaya meningkatkan kemampuan komunikasi matematis siswa. Sebagaimana disampaikan (Zed, 2004: 3) bahwa penelitian pustaka ialah serangkaian kegiatan yang berkenaan dengan metode pengumpulan data pustaka, membaca dan mencatat serta mengolah bahan penelitian. Kemudian teknik analisis yang digunakan adalah reduksi data, penyajian data dan penarikan kesimpulan sesuai dengan teknik analisis model Miles dan Huberman.

\section{Hasil dan Pembahasan \\ Komunikasi Matematis}

Menurut Kamus Besar Bahasa

Indonesia (Departemen Pendidikan Nasional, 2008:789), komunikasi adalah suatu proses pengiriman dan penerimaan antara dua orang atau lebih menggunakan cara yang tepat agar maksud dari pesan tersebut dapat diapahami. Komunikasi pada hakikatnya merupakan proses penyampaian pesan dari pengirim kepada penerima. Dalam proses tersebut terjadi interaksi antara pengirim dan penerima yang dapat dilakukan oleh dua orang atau lebih dalam menyampaikan pesan, informasi, dan gagasan secara jelas dan efisien sehingga maksud pesan tersebut dapat dipahami.

(Jazuli, 2009: 217) menyatakan bahwa kemampuan komunikasi matematis adalah kemampuan siswa untuk menyatakan suatu ide matematika melalui tulisan, bahasa, gambar, grafik, dan bentuk- bentuk visual lainnya. Sehingga siswa mampu memberikan pendapat untuk pemecahan suatu masalah.

Proses belajar mengajar hakikatnya adalah suatu proses komunikasi, antara guru dengan siswa ataupun siswa dengan siswa dalam menyampaikan materi pelajaran. Guru menyampaikan pesan berupa materi pembelajaran yang dituangkan ke dalam simbol-simbol. Pesan tersebut merupakan pengungkapan idea atau gagasan yang menggunakan bahasa matematis. Menurut (Mamluatul Mufida, 2015: 28) kemampuan komunikasi matematika adalah proses penyampaian suatu informasi dari pengirim kepada penerima sehingga isi dari informasi tersebut memiliki makna yang sama. Dengan komunikasi suatu ide dapat diperbaiki, kemudian dikembangkan menjadi lebih baik.

\section{Macam-macam Komunikasi Matematis}

\section{Kemampuan}

Menurut (Hodiyanto, 2017: 15)

Kemampuan komunikasi matematis seseorang terdiri dari dua hal yaitu lisan dan tulisan. Kemampuan komunikasi lisan contohnya adalah diskusi dan menjelaskan. Sedangkan dalam kemampuan komunikasi tulis contohnya mengungkapkan ide matematika melalui gambar/grafik, tabel, persamaan, ataupun dengan bahasa siswa sendiri.

(Sugiarto, 2014: 3) secara umum komunikasi matematis terbagi menjadi dua yaitu kemampuan komunikasi lisan dan tulis. Kemampuan komunikasi tulis adalah adalah kemampuan menyampaikan ide, gagasan, pendapat matematika kepada orang lain dalam bentuk kalimat matematika atau tulisan. Kemampuan komunikasi lisan adalah kemampuan seseorang menyampaikan ide, gagasan, pendapat matematika yang ada dalam pikirannya dalam bentuk lisan. Hal ini sejalan dengan dengan pendapat (Yulianto \& Suprihatiningsih, 2019: 372) yang menyatakan bahwa kemampuan komunikasi matematis terbagai menjadi dua yaitu komunikasi lisan (talking) dan komunikasi tulis (write). Komunikasi lisan dapat diketahui dari kegiatan siswa dalam 
menyampaikan ide atau gagasan dalam proses diskusi. Sedangkan kemampuan komunikasi tulis siswa dapat diketahui dari kemampuan siswa dalam menggunakan kalimat, notasi, atau struktur matematika dalam menghubungkan dan menyelesaikan suatu permasalahan dalam bentuk tulisan.

Dari beberapa pendapat tersebut maka dapat disimpulkan makna definisi kemampuan komunikasi matematis. Kemampuan komunikasi matematis adalah kesanggupan atau kecakapan seseorang menggunakan bahasanya sendiri secara tematik dalam menyampaikan gagasan atau ide matematika kepada orang lain dalam bentuk lisan maupun tulisan. Dengan kemampuan komunikasi matematis, informasi, pesan, dan gagasan yang disampaikan dapat dipahami orang lain dengan baik.

\section{Indikator Komunikasi Matematis}

Menurut NCTM dalam (Husna, M. Ikhsan, 2013: 85) indikator komunikasi matematis terbagi atas: (1) kemampuan menyampaikan ide matematis secara lisan dan tulis serta mengungkapkannya secara visual, (2) kemampuan memahami dan mengevaluasi ide matematis secara lisan, tulis, atau bentuk visual lainnya, (3) kemampuan menggunakan istilah-istilah, notasi matematika serta struktur dalam menyampaikan idenya. Berdasarkan pemaparan di atas indikator yang peneliti gunakan dalam penelitian ini adalah sebagai berikut

Tabel 1. Indikator Kemampuan Komunikasi Matematis Lisan

\begin{tabular}{|c|c|c|}
\hline No & $\begin{array}{c}\text { Aspek } \\
\text { Komunikasi } \\
\text { Matematis }\end{array}$ & $\begin{array}{c}\text { Indikator } \\
\text { Komunikasi } \\
\text { Matematis } \\
\text { Lisan }\end{array}$ \\
\hline \multirow[t]{2}{*}{1} & \multirow{2}{*}{$\begin{array}{l}\text { Kemampuan } \\
\text { mengekspresik } \\
\text { an ide-ide } \\
\text { matematika } \\
\text { melalui lisan } \\
\text { dan } \\
\text { mendemonstras } \\
\text { ikan serta }\end{array}$} & $\begin{array}{l}\text { Ketepatan } \\
\text { dalam } \\
\text { menyampaikan } \\
\text { materi kepada } \\
\text { teman } \\
\text { kelompoknya. }\end{array}$ \\
\hline & & $\begin{array}{l}\text { Kejelasan } \\
\text { berbahasa saat }\end{array}$ \\
\hline
\end{tabular}

\begin{tabular}{lll}
\hline & menggambarka & berbicara \\
n secara visual. & \\
\hline 2 & Kemampuan & Ketelitian \\
untuk & membaca \\
menggunakan & notasi \\
istilah-istilah, & matematika \\
notasi & dalam kegiatan \\
matematika dan & diskusi \\
\cline { 2 - 2 } struktur- & Kejelasan \\
strukturnya & penggunaan \\
dalam & bahasa secara \\
menyampaikan & lisan yang \\
ide matematika & mudah \\
serta & dimengerti \\
menggambarka & dalam \\
n hubungan- & penyampaian \\
hubungan & materi \\
dengan model- & \\
model situasi. & \\
\hline Kemampuan & Pemahaman \\
memahami, & materi yang \\
menginterprest & telah \\
asikan dan & disampaikan \\
mengevaluasi & oleh teman \\
ide-ide & kelompoknya \\
matematika & Ketepatan \\
baik secara & memberikan \\
lisan atau & pendapat dalam \\
bentuk visual & berdiskusi. \\
lainnya. & Kejelasan dan \\
& keakuratan \\
& dalam \\
& memberikan \\
& masukan sesuai \\
& teori \\
\hline & & \\
& & \\
& & \\
& & \\
& &
\end{tabular}

Tabel 2. Indikator Kemampuan Komunikasi Matematis Tulis

\begin{tabular}{|c|c|c|}
\hline No & $\begin{array}{c}\text { Aspek } \\
\text { Komunikasi } \\
\text { Matematis }\end{array}$ & $\begin{array}{c}\text { Indikator } \\
\text { Komunikasi } \\
\text { Matematis } \\
\text { Tulis }\end{array}$ \\
\hline \multirow[t]{2}{*}{1} & $\begin{array}{l}\text { Kemampuan } \\
\text { mengekspresika } \\
n \text { ide-ide } \\
\text { matematika } \\
\text { melalui tulis dan } \\
\text { mendemonstrasi }\end{array}$ & $\begin{array}{l}\text { Menyelesaikan } \\
\text { permasalahan } \\
\text { dengan } \\
\text { menuliskan ide } \\
\text { dari hasil } \\
\text { pemikirannya. }\end{array}$ \\
\hline & $\begin{array}{l}\text { kan serta } \\
\text { menggambarkan } \\
\text { secara visual. }\end{array}$ & $\begin{array}{l}\text { Menginterprest } \\
\text { asikan ide } \\
\text { matematika }\end{array}$ \\
\hline
\end{tabular}




\begin{tabular}{|c|c|c|}
\hline & & $\begin{array}{l}\text { dalam bentuk } \\
\text { gambar atau } \\
\text { persamaan. }\end{array}$ \\
\hline 2 & $\begin{array}{l}\text { Kemampuan } \\
\text { menggunakan } \\
\text { istilah-istilah, } \\
\text { notasi } \\
\text { matematika } \\
\text { serta struktur- } \\
\text { strukturnya }\end{array}$ & $\begin{array}{l}\text { Menggunakan } \\
\text { representasi } \\
\text { untuk } \\
\text { menyatakan } \\
\text { konsep } \\
\text { matematika } \\
\text { secara tulis. }\end{array}$ \\
\hline & $\begin{array}{l}\text { dalam } \\
\text { menyampaikan } \\
\text { ide matematika, } \\
\text { serta } \\
\text { menghubungkan } \\
\text { nya dengan } \\
\text { model-model } \\
\text { situasi. }\end{array}$ & $\begin{array}{l}\text { Menguraikan } \\
\text { solusi yang } \\
\text { ditemukan } \\
\text { melalui tulis. }\end{array}$ \\
\hline 3 & $\begin{array}{l}\text { Kemampuan } \\
\text { memahami, } \\
\text { menginterpresta } \\
\text { sikan dan } \\
\text { mengevaluasi } \\
\text { ide-ide } \\
\text { matematika baik } \\
\text { secara tulis } \\
\text { maupun dalam } \\
\text { bentuk visual } \\
\text { lainnya. }\end{array}$ & $\begin{array}{l}\text { Menuliskan ide } \\
\text { pemikirannya } \\
\text { untuk } \\
\text { menemukan } \\
\text { solusi } \\
\text { penyelesaian } \\
\text { permasalahan } \\
\text { yang ada } \\
\text { menggunakan } \\
\text { istilah-istilah } \\
\text { dan notasi- } \\
\text { notasi } \\
\text { matematika } \\
\text { secara tepat }\end{array}$ \\
\hline & & $\begin{array}{l}\text { Menyajikan } \\
\text { pendapatnya } \\
\text { yaitu berupa } \\
\text { penyelesaian } \\
\text { permasalahan } \\
\text { yang ditulis } \\
\text { pada lembar } \\
\text { kerja siswa } \\
\text { secara } \\
\text { terstruktur. }\end{array}$ \\
\hline
\end{tabular}

\section{Model Pembelajaran Kooperatif}

(Hartoto, 2016: 134) Pembelajaran kooperatif adalah strategi pembelajaran dalam kelompok kecil dimana siswa saling bekerjasama untuk menciptakan suasana belajar yang efektif dalam memaksimalkan tercapainya tujuan pembelajaran. (Abdullah, 2017: 21) pembelajaran kooperatif ialah suatu model pembelajaran yang menekankan pada interaksi antar siswa dalam berbagi informasi dan pengetahuan yang dimiliki. Pembelajaran kooperatif (Cooperative Learning) merupakan salah satu model pembelajaran yang didasarkan pada teori belajar kontruktivisme dan efektif digunakan dalam proses pembelajaran dikarenakan siswa memperoleh pengetahuan tidak hanya dari guru tetapi juga dari proses interaksi saat diskusi.

Model pembelajaran kooperatif fokus pada kelompok kecil (3-5) siswa yang heterogen hal ini berbanding terbalik dengan model pembelajaran klasikal yang berfokus pada siswa satu kelas 30-40 siswa. Sehingga menurut (Roestiyah, 2008) model pembelajaran kooperatif efektif digunakan untuk menyampaikan materi, menciptakan kondisi belajar yang kondusif dan interaktif yang dapat dilihat dari interaksi belajar siswa dalam kelompok diskusi. Selain memiliki keunggulan pembelajaran kooperatif juga memiliki kelemahan antara lain sulitnya membentuk kelompok yang bekerjasama dengan harmonis, anggota kelompok yang malas mungkin dapat cenderung bergantung kepada teman yang lebih pintar, banyak juga yang perbendapat bahwa model pembelajaran kooperatif menguntungkan anggota yang malas karena hanya menggantungkan diri pada temannya.

\section{Think Talk Write Pengertian Think Talk Write} Huinker \& Laugin memperkenalkan model Pembelajaran Kooperatif yang dikenal dengan Think Talk Write (TTW). Model pembelajaran ini dibangun dari tiga aspek penting yaitu proses berpikir, berbicara, dan menulis (Ratna Prasasti Suminar, 2015) Alur dari model pembelajaran ini dimulai dari keterlibatan siswa untuk berpikir melalui bahan bacaan, kemudian hasilnya akan di diskusikan dalam kelompok dan terakhir mengkonstruksikan apa yang telah mereka baca dan diskusikan dengan menulis kesimpulan secara mandiri. Uraian tentang model pembelajaran kooperatif tipe Think Talk Write (TTW) menurut (Ratna Prasasti Suminar, 2015: 300)adalah sebagai berikut: 
a. Think ( Berpikir)

Pada tahap berpikit "think" siswa dapat dilihat dari proses pembelajaran ketika siswa membaca soal matematika. Secara mandiri, siswa memikirkan gagasan mengenai sesuatu yang diketahui atau belum diketahui kemudian menjadikannya sebagai catatan kecil.

b. Talk (Berbicara )

Pada tahap "talk" terjadi proses yaitu siswa mendiskusikan catatan kecil yang mereka peroleh dari tahap "think" dengan kelompok masing-masing. Pada tahap ini siswa berlatih untuk berani mengungkapkan pendapat mereka

c. Write (Menulis)

Terakhir adalah fase "write" yaitu menuliskan hasil diskusi pada lembar kerja siswa secara individu dengan menggunakan bahasanya sendiri. Dalam aktivitas menulis berarti siswa mampu mengkonstruksi ide yang diperoleh dari diskusi kelompok

\section{Langkah-langkah Think Talk Write}

Model pembelajaran Think Talk

Write (TTW) dikembangkan oleh Huinker dengan langkah-langkah yang dikutip oleh (Shoimin, 2014: 214-215) sebagai berikut:

1. Mengkondisikan Keadaan Kelas.

Guru mengkondisikan

kelas dan juga siswa untuk siap belajar. kemudian, menjelaskan tujuan pembelajaran, dan membagikan LKS yang memuat soal yang harus dikerjakan oleh siswa serta petunjuk pelaksanaannya.

2. Membaca LKS dan Membuat Catatan kecil

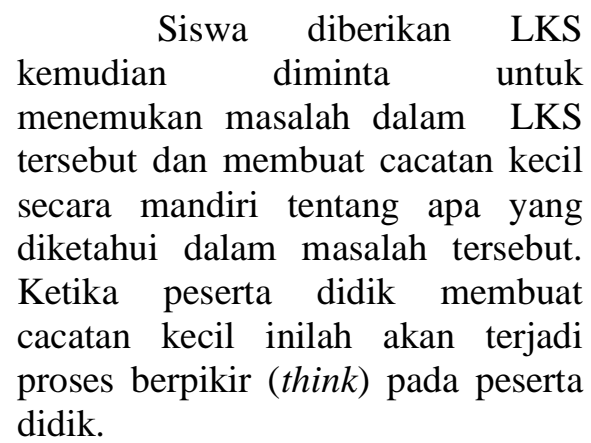

3. Membentuk Kelompok

Guru membagi siswa

dalam kelompok kecil (3-5 siswa)

yang heterogen.

4. Diskusi Kelompok

Dalam proses diskusi siswa

saling berbagi pemikiran atau pendapat untuk menemukan kesesuaian isi dari catatan dengan menggunkan kalimat mereka sendiri.. Diskusi diharapkan mampu menemukan solusi yang tepat dari LKS yang telah diberikan.

5. Mempresentasikan Hasil Diskusi Dari hasil kegitan diskusi sebelumnya siswa secara mandiri dapat merumuskan pengetahuan berupa jawaban soal (berisi landasan dan keterkaitan konsep,metode, dan solusi) dalam bentuk tulisan (write) dengan bahasanya sendiri. Kemudian guru menunjuk salah satu kelompok untuk mempersentasikan hasil diskusi dan kelompok lain memberikan sanggahan dan tanggapan.

6. Merefleksi Hasil Diskusi Dari hasil diskusi yang telah dipresentasikan oleh setiap perwakilan kelompok, guru beserta siswa melakukan refleksi dan membuat kesimpulan. Hal ini dilakukan agar hasil diskusi lebih dipahami oleh siswa.

\section{Kelebihan dan Kekurangan Think Talk Write}

Menurut (Purwanto, 2012: 55) model pembelajaran Think Talk Write (TTW) memiliki kelebihan dan kelemahan sebagai berikut:

a. Kelebihan Model Pembelajaran Think Talk Write

1. Membangun dan menumbuhkan kemandirian siswa dalam belajar.

2. Setiap siswa diperbolehkan untuk berkolaborasi sehingga terjadi interaksi antara siswa yang dapat meningkatkan kemampuan berbicara siswa.

3. Hasil pembelajaran lebih mudah dipahami oleh siswa 
karena hasil diskusi ditulis dengan bahasanya sendiri.

b. Kekurangan Model Pembelajaran Think Talk Write (TTW)

1. Banyak siswa yang bertanya kepada guru sehingga perlu dipantau.

2. Siswa yang pintar akan mendominasi jalannya diskusi.

3. Diperlukannya waktu yang lama untuk diskusi mendalam.

Dari langkah-langkah Think Talk Write (TTW) dapat diketahui bahwa model pembelajaran tersebut dibangun dari tiga aspek penting yaitu proses berpikir (think), berbicara (talk) dan menulis (write) yang dapat meningkatkan kemampuan komunikasi matematis baik secara lisan dan tulis. Dikarenakan dalam menerapakan model pembelajaran Think Talk Write (TTW) siswa dibiasakan untuk menyampaikan ide atau gagasannya untuk melatih kemampuan komunikasi lisan siswa dalam proses diskusi dan juga menulis kembali hasil pembelajaran dengan bahasanya sendiri untuk meningkatkan kemampuan komunikasi tulis. Hal ini juga dapat dilihat dari kelebihan model pembelajaran Think Talk Write (TTW) yang dapat meningkatkan kemampuan komunikasi matematis siswa jika model pembelajaran ini diterapkan.

\section{Simpulan dan Saran Simpulan}

Berdasarkan telaah pustaka ilmiah maka dalam artikel ini dapat disimpulkan bahwa kemampuan komunikasi matematis penting untuk dimiliki oleh siswa, sebab pentingnya komunikasi matematis tersebut maka kemampuan komunikasi matematis dapat ditingkatkan dengan model pembelajaran Think Talk Write (TTW), mengingat komunikasi matematis memuat aspek kemampuan menyampaikan gagasan atau ide kepada orang lain secara lisan dan tulis. Dimana hal ini sangat didukung oleh model pembelajaran Think Talk Write (TTW) yaitu pada langkah-langkah berpikir (think) secara mandiri dimulai dari membaca berbagai sumber belajar, berbicara (talk) melatih siswa menyampaikan gagasan atau ide kepada orang lain dan langkah terakhir yaitu menulis (write) menulis kembali hasil pembahasan dengan bahasanya sendiri.

\section{Saran}

Saran untuk penelitian selanjutnya adalah model pembelajaran Think Talk Write (TTW) dapat dijadikan salah satu alternatif yang dapat diterapkan dalam proses pembelajaran untuk meningkatkan kemampuan komunikasi matematis siswa. (Sugandi, 2011: 48) menyatakan bahwa model pembelajaran Think Talk Write (TTW) dapat meningkatkan kemampuan komunikasi matematis siswa. Diharapkan juga dilakukan penelitian lebih lanjut dengan menggunakan metode lain yang dapat meneliti kemampuan komunikasi matematis siswa. Selain model pembelajaran mungkin ada beberapa faktor yang dapat mempengruhi kemampuan komunikasi matematis siswa.

\section{Daftar Pustaka}

Abdullah, R. (2017). Pengaruh Penerapan Model Pembelajaran Kooperatif Tipe Jigsaw Pada Mata Pelajaran Kimia Di Madrasah Aliyah. Lantanida Journal, 5(1), Https://Doi.Org/10.22373/Lj.V5i1.205 6

Andriani, D., Suhendri, H., \& Liberna, H. (2019). Pengaruh Metode Pembelajaran Lightening The Learning Climate Terhadap Kemampuan Komunikasi Matematis Peserta Didik. Sigma, 5(1), 22. Https://Doi.Org/10.36513/Sigma.V5i1 .637

Hartoto, T. (2016). Model Pembelajaran Kooperatif Tipe Group Investigation (Gi) Meningkatkan Aktivitas Dan Hasil Belajar Sejarah. Historia, 4(2), 131. Https://Doi.Org/10.24127/Hj.V4i2.55 3 
Hodiyanto. (2017). Kemampuan Komunikasi Matematis Dalam Pembelajaran Matematika. 7(1).

Husna, M. Ikhsan, S. F. (2013). Peningkatan Kemampuan Pemecahan Masalah Dan Komunikasi Matematis Siswa Sekolah Menengah Pertama Melalui Model Pembelajaran Kooperatif Tipe Think-Pair-Share (Tps). Jurnal Peluang, 1(2), 81-92.

Inah, E. N. (2015). Peran Komunikasi Dalam Interaksi Guru Dan Siswa. AlTa'dib, 8(2), 150-167.

Jazuli, A. (2009). Berpikir Kreatif Dalam Kemampuan Komunikasi Matematika. Prosiding Seminar Nasional Matematika Dan Pendidikan Matematika, 209-220. Https://Eprints.Uny.Ac.Id/7025/1/P11 -Akhmad Jazuli.Pdf

Khoiruddin, M. A. (2012). Peran Komunikasi, Oleh: M. Arif Khoiruddin. 23, 118-131.

L. Winayawati? , S.B. Waluya, Dan I. J. (2012). Implementasi Model Pembelajaran Kooperatif Dengan Strategi Think-Talk-Write Terhadap Kemampuan Menulis Rangkuman dan Pemahaman Matematis Materi Integral. Unnes Journal Of Research Mathematics Education, 1(1), 70. Https://Doi.Org/10.24114/Bss.V6i2.6 378

Lusi Ari Sumirat. (2014). Efektifitas Strategi Pembelajaran Kooperatif Tipe Think-Talk-Write (TTW) Terhadap Kemampuan Komunikasi Dan Disposisi Matematis Siswa. 1(2), 24. Https://Doi.Org/10.1111/17549485.12569

Mamluatul Mufida. (2015). Analisis Kemampuan Komunikasi Matematis Pada Model Pbl Dengan Pendekatan Saintifik Berdasarkan Gaya Belajar Siswa Kelas VIII.
National Council Of Teachers Of Mathematics. (2000). Principles And Standard For School Mathematics. NCTM.

Nazir. (2003). Metode Penelitian. Ghalia Indonesia.

Purwanto, B. (2012). Eksperimentasi Model Pembelajaran Kooperatif Tipe ThinkTalk-Write (TTW) Dan Tipe ThinkPair-Share (TPS) Pada Materi Statistika Ditinjau Dari Kemandirian Belajar Siswa SMA Di Kabupaten Madiun.

Ratna Prasasti Suminar. (2015). The Effectiveness Of Ttw (Think-TalkWrite) Strategy In Teaching Writing Descriptive Text. Journal Of English Language And Learning, 2(2).

Roestiyah. (2008). Strategi Belajar Mengajar. Jakarta: Rineka Cipta.

Shoimin, A. (2014). 68 Model Pembelajaran Inovatif Dalam Kurikulum 2013. Yogyakarta: ArRuzz Media.

Sugandi, A. I. (2011). Pengaruh Model Pembelajaran Koperatif Tipe Think Talk Write Terhadap Kemampuan Komunikasi. Makalah Dalam Seminar Nasional Matematika Dan Pendidikan Matematika FMIPA, 41-50.

Sugiarto. (2014). Kemampuan Komunikasi Matematika Siswa Smp Dalam Pemecahan Masalah Ditinjau Dari Kemampuan Matematika. 3(3), 1-6.

Wardhani, S., \& Rumiati. (2011). Better Education Through Reformed Management And Instrumen Penilaian Hasil Belajar Matematika SMP : Belajar Dari PISA Dan TIMSS. Yogyakarta: PPPPTK Matematika, 55.

Yulianto, H., \& Suprihatiningsih, S. (2019). Kemampuan Komunikasi Matematis Siswa Pada Pembelajaran Treffinger 
Berdasarkan Self Efficacy. 2017, 7.

Indonesia.

Zed, M. (2004). Metode Penelitian Kepustakaan. Jakarta: Yayasan Obor 